14 feet 6 in. $(8.62 \mathrm{~m}, \times 14.42 \mathrm{~m}, \times 442)$ in height. In the centre of this house a banana palm and a few other small palmtrees are planted, the sides of the house all round being occupied with a considerable variety of flowering plants. The electric light was fixed as high as practicable at the south corner of the house, in order that its rays might fall upon the plants from a direction and at an angle coincident with those of the sun during the middle of the day. The temperature of the house was maintained at $65^{\circ} \mathrm{F}$, and the electric lamp was kept alight from 5 P.M. to 6 A.M., for one week, from February 18 to February 24, excepting Sunday night. The time was hardly sufficient to produce very striking effects, but all the plants continued to present a healthy appearance. Of three Alicante vines, the one nearest the electric light made most progress, and the same could be said of the nectarines and roses. It was observed that other plants, such as geraniums, continued to exhibit a vigorous appearance, notwithstanding the heat of the place. This experiment is of importance in showing that the electric light, if put into conservatories or greenhouses, does not injure the plants, but rather improves their appearance and growth. The leaves assume a darker and more vigorous appearance, and it seems that the colouring of the flowers becomes more vivid, but a further period of time is necessary to establish this observation absolutely.

I decided to try the effect of electric light as a means of pro. moting growth in the open air and under glass at the same time.

The regulator was put back into its first position, 2 metres above the ground, with a sunken melon house on one side, and a sunken house containing roses, lilies, strawberries, and a variety of other plants on the other. The space of ground between these, about I metre broad and 7 metres long, was covered with boxes sown with early vegetables, including mustard, peas, beans, and potatoes, and in order to prevent cold winds from injuring the plants, low protecting walls were put up across the openings of the passage between the two houses.

Some weeks must elapse before any absolute results can be given, but growth is evidently promoted under all these various circumstances. In order to test this clearly, a portion of the plants both under glass and in the open air are shaded from the electric light without removing them from their position of equal temperature and exposed to solar light during daytime. The effect upon the flowering plants is very striking, electric light being apparently more efficacious to bring them on than daylight. Although the amount of heat given off from the electric arc is not great compared with a gas flame (giving off its products of combustion), yet the rays of intense heat of the arc counteract that loss of heat by radiation from the leaves into space, which during a clear night causes hoar frost. For this reason I expect that electric light may be usefully employed in front of fruit walls, in orchards, and in kitchen gardens, to save the fruit-bud at the time of setting; and in this application electric light will probably be found a useful agent not only to promote rapid growth, but to insure a better yield of fruit.

The experiments seem to lead to the following conclusions :-

I. That electric light is efficacious in producing chlorophyll in the leaves of plants, and in promoting growth.

2. That an electric centre of light, equal to I, 400 candles, placed at a distance of 2 metres from growing plants, appeared to be equal in effect to average daylight at this season of the year, but that more economical effects can be attained by more powerful light centres.

3. That the carbonic acid and nitrogenous compounds generated in diminutive quantities in the electric arc, produce no sensible deleterious effects upon plants inclosed in the same space.

4. That plants do not appear to require a period of rest during the twenty-four hours of the day, but make increased and vigorous progress if subjected during daytime to sunlight and during the night to electric light.

5. That the radiation of heat from powerful electric arcs can be made available to counteract the effect of night frost, and is likely to promote the setting and ripening of fruit in the oren air.

6. That while under the influence of electric light plants can sustain increased stove heat without collapsing, a circumstance favourable to forcing by electric light.

7. -That the expense of electro-horticulture depends mainly upon the cost of mechanical energy, and is very moderate where natural forces of such energy, such as waterfalls, can be made available.

Since writing the above my attention has been drawn to an article in NATURE, vol. xxi. p. $3 \mathbf{I} \mathbf{I}$, giving interesting observations by Dr. Schübeler, of Christiania, on "The Effect of Uninterrupted Sunlight on Plants in the Arctic Regions." These observations fully confirm the conclusion indicated by my experiments with electric light. Not only are plants able to grow continuously, according to Dr. Schübeler, but when under the influence of continuous light, they develop more brilliant flowers and larger and more aromatic fruit than under the alternating influence of light and darkness, whereas the formation of sugar appears to be dependent chiefly upon temperature.

It would follow from these observations, that with the aid of stoves and electric light, fruit, excelling both in sweetness and aroma, and flowers of great brightness, may be grown without solar aid. Dr. Schuibeler mentions that in removing an acacia plant from the dark, and flacing it under the influence of the Arctic midnight sun, the leaves opened slowly, and it is interesting to observe that the same effect took place when an Acacia Lophantha was placed (in the open air) under the influence of my midnight lamp.

\section{PREHISTORIC ANTIQUITIES OF THE AUSTRIAN EMPIRE}

I. CAVES.-The cave of Vypustek, near Brün, in Moravia, was systematically explored, from A pril to end of October 1879 , under the superintendence of the Committee, appointed by the Imperial Academy of Sciences at Vienna, for Prehistoric Investigations. The ossiferous layer, four to five metres thick, and covered with a thin stalagmite, is a non-stratified breccia of sand, loam, pebbles, and angular stones, with bones of "diluvial " mammals abundantly, but irregularly, dispersed. Most of the bones are fragmentary; many of the pieces are rolled, and even polished, by friction. Bones of Ursus spelaus predominate. Eight to ten per cent. belong to thirty other mammalian species. Some bones have evidently been gnawed by porcupines. In a side cave, layers of charcoal and ashes, with fragments of rudely-worked stone implements and bones of domestic animals, showed it to have been once resorted to by human beings.

The Kreuzberg Cave in Carniola has further enriched the Academy's museum with numerous remains of Ursus spelaus. Skeletons of individuals of all ages lie together, but only in the uppermost loam in the highest part of the cave. Thus the animals inhabiting the cave may be supposed to have retired before an irruption of water, and have perished by a flood in in their place of retreat. In a side cave the stalagmitic floor near the entrance contains some charred corn.

A cave near Fiume, on the Adriatic coast, opened by railway. works, appears to have been used as a burial-place in the stone period, as human skeletons, bones of animals, stone implements, and fragments of rude earthenware, were discovered in it.

2. Tumuli.-A tumulus opened in Lower Austria was found to contain only a few worked stones, layers of charcoal, and bones of animals. The skeleton of a woman, executed and buried about seventy years ago, lay in its uppermost portion. In the same province several low barrows were found to contain stones placed in a circle, in the middle of which, on a stone slab, lay the skeleton (not burnt), with many bronze weapon and ornaments. Some larger barrows, probably of later date, are reported to have contained urns and charred bones, a few objects of bronze and iron, and coins of Domitian.

Of more than a hundred tumuli near St. Margareth, Lower Carniola, twenty have been opened. A great many antiquities were obtained: earthen vases of peculiar shape, articles in bronze, iron, glass, and amber, and even gold ornaments.

The tumuli near Jagnenza were found to contain skeletors within elliptical rows of stones, and those near Unter-Erkerstein had urns with burnt haman bones. Another large barrow con tained a circle of stones, a human skeleton, burnt bones, char coal, iron objects, and bronze ornaments.

\section{NOTES FROM ITALY AND SICILY}

THE following notes, although necessarily of a desultory character, may interest some of our readers :-

Climate.-The climate of Southern Europe during the last month, from the middle of December to January 20 , has been more severe than we ever remember it before. Long icicles depended from the platform of the engine which conveyed us

${ }^{x}$ Report of the Committee, \&c., Imperial Academy of Vienna. Repirt of Meeting, December 18, r879. 